\title{
Decision analysis support for evaluating transmission risk of COVID-19 in places where people gather
}

\author{
Valerie Hongoh ${ }^{1 *}$, David Maybury², Jérôme Levesque ${ }^{2}$, Aamir Fazil ${ }^{3}$, Ainsley Otten ${ }^{3}$, \\ Patricia Turgeon ${ }^{1}$, Lisa Waddell', Nicholas H Ogden ${ }^{1}$
}

\begin{abstract}
Background: The coronavirus diseases 2019 (COVID-19) pandemic has presented an unprecedented public health challenge. Prior to vaccination, non-pharmaceutical interventions, including closures, were necessary to help control the epidemic. With the arrival of variants of concern and insufficient population vaccination coverage, ongoing evaluation of transmission risk in settings and the use of non-pharmaceutical interventions are necessary to help control the epidemic. This study aimed to produce a framework for evaluating transmission risk in settings where individuals gather and inform decision-making.
\end{abstract}

Methods: A multi-criteria decision analysis process was used to structure the framework. Fifteen criteria were identified as important to consider for COVID-19 transmission risk based on the literature. This list was ranked by experts and then categorized. The analysis was structured by the consensus list of criteria and relative positioning of each criteria within the list to produce sets of factors to consider when assessing transmission risk at gatherings.

Results: Fifteen experts from across Canada participated in ranking the criteria. Strong consensus was found on the relative importance of criteria and this relative consensus was used to create four categories: critical ( 3 criteria); important ( 6 criteria); good to consider ( 5 criteria); and if time permits (1 criterion).

Conclusion: The resulting consensus list and categories constitutes a set of important elements that can be applied to any setting as an objective and transparent framework to assess transmission risk in the venue. In conjunction with further consideration of the local epidemiology of COVID-19, an overall risk of transmission assessment can be established and uniformly implemented.
This work is licensed under a Creative Commons Attribution 4.0 International License.

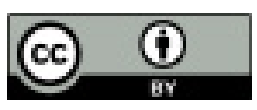

Affiliations

${ }^{1}$ Public Health Risk Sciences Division, Public Health Agency of Canada, St Hyacinthe, QC

${ }^{2}$ Public Services and Procurement Canada, Ottawa, ON

${ }^{3}$ Public Health Risk Sciences Division, Public Health Agency of Canada, Guelph, ON

${ }^{4}$ National Microbiology Laboratory, Public Health Agency of Canada, Winnipeg, MB

*Correspondence: valerie.hongoh@phac-aspc.gc.ca

Suggested citation: Hongoh V, Maybury D, Levesque J, Fazil A, Otten A, Turgeon P, Waddell L, Ogden NH. Decision analysis support for evaluating transmission risk of COVID-19 in places where people gather. Can Commun Dis Rep 2021;47(11):446-60. https://doi.org/10.14745/ccdr.v47i11a02

Keywords: SARS-CoV-2, COVID-19, transmission risk, gatherings, systematic evaluation

\section{Introduction}

The emergence of the novel coronavirus severe acute respiratory syndrome coronavirus 2 (SARS-CoV-2) and the associated disease (coronavirus disease 2019; COVID-19) was initially observed as an outbreak in Wuhan, China in late 2019, and resulted in the ongoing pandemic (1). The virus was first detected in Canada in early 2020 and has caused 1,670,241 cases and 28,367 deaths (as of October 13, 2021) (2). The SARS-CoV-2 is a highly transmissible respiratory virus that can cause a range of symptoms from none to mild or severe disease and death (3). This has created an unprecedented disease management challenge for public health and numerous public health measures have been implemented with variable stringency in an attempt to slow the epidemic and reduce its impact. These include increased personal physical distancing and non-pharmaceutical interventions, such as case detection and isolation, tracing of contacts and quarantine and community masking (4), to reduce transmission opportunities in the community. However, when and where transmission is high, a range of restrictive closures have been imposed by provincial and local governments, including closures of schools, universities and non-essential businesses, bans or limitations on gatherings, limitations on travel within and between jurisdictions and encouragement of teleworking in 
an attempt to limit transmission opportunities. Together these actions helped to minimize person-to-person contacts in Canada and resulted in the epidemic coming under control with low reported case incidence during summer 2020. However, the fall 2020 return to school and re-opening of businesses in many regions of Canada resulted in a resurgence of the epidemic and a second wave peaking higher in total cases, hospitalizations and deaths than the spring wave (2). As capacity for control of the epidemic by testing and tracing alone was surpassed, re-implementation of some levels of restrictive closures was deemed necessary to help reduce rates of contact between Canadians, regain previous levels of epidemic control and limit the risk of exceeding healthcare capacity. Closures of schools and businesses have important social and economic impacts on society. The challenge facing decision-makers is how to navigate the trade-off between preventing COVID-19 transmission and the negative potential health, social and economic impacts of restrictive measures (5-12). A full assessment that includes negative impacts of closures is outside the scope of this work, as at this time the focus is restricted to informing assessment of transmission risk.

The arrival of vaccine doses in Canada in December 2020 raised hopes that restrictive measures could be eased. However, the recent emergence of new, more transmissible and in some cases more virulent variants of concern (VOC) meant that caution was and will be needed when lifting restrictive measures and re-opening businesses and places where people gatherparticularly until sufficient vaccination coverage and natural immunity of the Canadian population has been achieved. Even then, the capacity to inform decisions on restrictive closures will remain relevant with the continuing threat of immune escape $\mathrm{VOC}$ and the potential of waning immunity.

This project began in late 2020, prior to vaccine arrival in Canada, with the aim to explore available evidence on COVID-19 transmission in different settings and contribute to informing decision-making around closures. Settings are meant to broadly encompass all locations presenting a transmission risk for COVID-19 that a decision-maker may wish to assess. These include transmission at private gatherings in people's homes, as well as transmission in public places such as schools, grocery stores, retail stores, concerts and bars among others. The explicit consideration of high-risk populations can also be included in the assessment. While the potential cascading effects of closures are numerous and still being studied, characteristics of a setting contributing to transmission risk remains independently important to evaluate, even as vaccination is being rolled out since the presence of variants of concern continues to pose an important transmission risk. The objective of this project was to produce a framework to assist in ranking settings by the risk they pose for COVID-19 transmission, and potentially identify areas where mitigating measures can be targeted to help reduce transmission risk in these same settings in order to help inform decision-making.

\section{Methods}

Multi-criteria decision analysis (MCDA) is part of a family of decision aid tools from the field of operations research and used in numerous sectors to systematically evaluate alternatives over multiple criteria (13). Multi-criteria decision analysis approaches help to structure reflection around a decision problem by allowing the integration of multiple types of evaluations and the highlighting of strengths and weaknesses of the alternatives under evaluation. Participatory MCDA processes generally consist of a multi-step problem structuring phase where the problem is defined, stakeholders identified, criteria defined and weighted, items to be ranked identified and evaluated over the criteria, followed by a decision analysis phase where the multi-criteria analysis is carried out along with a sensitivity analysis and interpretation of results (Table 1 ). In this article, a "rapid and light" version of a participatory MCDA process was used to structure a framework for the evaluation of settings at risk for COVID-19 transmission, while taking into account time constraints of stakeholders and considerable data gaps in the literature. The objective was to identify criteria and indicators that would be most informative for assessing transmission risk in settings and produce a consensus ranking of these criteria by experts. The results of this exercise are presented along with a discussion of how the results could be used to help assess settings for transmission risk.

\section{Table 1: Summary of steps in participatory and "light" multi-criteria decision analysis process}

\begin{tabular}{|c|c|c|c|}
\hline Phase & $\#$ & $\begin{array}{c}\text { Steps included in } \\
\text { the participatory } \\
\text { process }\end{array}$ & $\begin{array}{l}\text { Steps included in } \\
\text { the "light" process }\end{array}$ \\
\hline \multirow{6}{*}{$\begin{array}{l}\text { Problem } \\
\text { structuring }\end{array}$} & 1 & $\begin{array}{l}\text { Definition of the } \\
\text { problem of interest }\end{array}$ & $x$ \\
\hline & 2 & $\begin{array}{l}\text { Identification of } \\
\text { stakeholders }\end{array}$ & $x$ \\
\hline & 3 & $\begin{array}{l}\text { Identification of } \\
\text { alternatives }^{b}\end{array}$ & - \\
\hline & 4 & Definition of criteria & $x$ \\
\hline & 5 & Weighting of criteria & $x$ \\
\hline & 6 & $\begin{array}{l}\text { Evaluation of } \\
\text { alternatives }{ }^{b} \text { based on } \\
\text { criteria }\end{array}$ & - \\
\hline \multirow{3}{*}{$\begin{array}{l}\text { Decision } \\
\text { analysis }\end{array}$} & 7 & Decision analysis & - \\
\hline & 8 & Sensitivity analysis & - \\
\hline & 9 & Interpretation of results & - \\
\hline
\end{tabular}

Four steps from a participatory MCDA methodology were adapted to allow for the construction of an expert-ranked consensus list of criteria that could be used as a decision-aid. A quick scan of the literature was conducted to search for broad 
factors contributing to COVID-19 transmission risk and produce a preliminary list of key criteria. The scan was conducted in an evergreen database of COVID-19 literature maintained within the Public Health Agency of Canada that compiles citations daily from seven databases. The search was used to draft an initial list of twenty-three criteria, and indicators for their rapid evaluation. A limited number of studies were available and consisted primarily of rapid reviews of reports where clusters had occurred with many of the early outbreaks reported having occurred before widespread use of public health measures. Preliminary criteria related to common factors present in settings where outbreaks had occurred. Droplet and aerosol transmission was thought to account for most transmissions and pointed towards elements favoring close contact in closed and crowded spaces as primary drivers of transmission.
The preliminary list of criteria was presented to a group of 62 provincial public health experts for review and comment. The list was condensed to 15 criteria, including 10 site and event characteristics, one participant-level characteristic and four potential mitigation measures (Table 2). In order to keep the final number of criteria manageable, a number of criteria from the original list were combined (e.g. indoor/outdoor location and ventilation) and criteria to evaluate secondary activities at settings were not included (e.g. shared dining or break rooms). This list was then presented to a group of experts within the Pan-Canadian Public Health Network involved in the COVID-19 response, for ranking during December 2020 via an online tool created explicitly for this purpose. The individual expert-ranked lists were combined using general Mallows models (14) to produce a consensus ranking (see Appendix for more details on the general Mallows models). The R package PerMallows (15) was used to analyze the rankings.

\section{Table 2: Criteria for evaluating transmission risk in settings}

\begin{tabular}{|c|c|c|c|c|}
\hline Criteria & $\begin{array}{l}\text { Level (from lower to } \\
\text { higher risk) }\end{array}$ & Summary: What is known & Examples & References \\
\hline $\begin{array}{l}\text { Location and } \\
\text { ventilation }\end{array}$ & $\begin{array}{l}\text { 1. Outdoors } \\
\text { 2. Indoors good } \\
\text { ventilation (well- } \\
\text { designed mechanical } \\
\text { - HVAC) } \\
\text { 3. Indoors with } \\
\text { moderate ventilation } \\
\text { (windows) } \\
\text { 4. Indoors poor } \\
\text { ventilation }\end{array}$ & $\begin{array}{l}\text { Risk of transmission generally thought to be lower } \\
\text { outdoors depending on nature of setting, activity type, } \\
\text { duration, circulation and providing physical distancing at or } \\
\text { around } 2 \text { meter can be maintained. } \\
\text { Weed et al. report limited evidence of outdoor } \\
\text { transmission based on reviewed studies. Some outdoor } \\
\text { transmission has occurred when physical distancing was } \\
\text { breached or in high density conditions, low circulation, } \\
\text { large size of gatherings over extended duration has taken } \\
\text { place (e.g. outdoor concerts, festivals, some physical } \\
\text { activities, sporting events). } \\
\text { Risk of transmission in closed environments reported to be } \\
\text { higher than in open-air environments (OR } 18.7 \text { (6.0-57.9)). } \\
\text { Note: cases in study occurred when social interactions } \\
\text { were unrestricted. } \\
\text { ECDC concluded that well maintained HVAC systems } \\
\text { adapted for use in COVID-19 pandemic may help to } \\
\text { decrease airborne transmission. } \\
\text { HVAC - contamination in air samples and HVAC system } \\
\text { surfaces in healthcare settings indicate possible spread but } \\
\text { virus viability not established. } \\
\text { Some early case clusters were attributed to air } \\
\text { conditioning units and air recirculation. Air jets from AC } \\
\text { and recirculation of indoor air considered likely modes of } \\
\text { transmission. } \\
\text { Other coronavirus infections have been associated with } \\
\text { poor ventilation (insufficient movement and clearance of } \\
\text { contaminated indoor air). }\end{array}$ & $\begin{array}{l}\text { Indoor examples: } \\
\text { Gyms, fitness class, } \\
\text { recreational sports, } \\
\text { workplaces. Nightclubs } \\
\text { with poor ventilation, } \\
\text { crowding and loud music } \\
\text { leading to attendees } \\
\text { potentially yelling and } \\
\text { leaning very close } \\
\text { together to communicate; } \\
\text { Karaoke rooms } \\
\text { Parties, restaurants, } \\
\text { healthcare facilities } \\
\text { Outdoor examples: } \\
\text { Local festivals, events with } \\
\text { tented eating spaces with } \\
\text { poor ventilation }\end{array}$ & $(16-23)$ \\
\hline $\begin{array}{l}\text { Duration of } \\
\text { event (time) }\end{array}$ & $\begin{array}{l}\text { 1. Interaction less than } \\
5 \text { minutes } \\
\text { 2. } 5-14 \text { minutes } \\
\text { 3. } 15-60 \text { minutes } \\
\text { 4. More than } 60 \\
\text { minutes }\end{array}$ & $\begin{array}{l}\text { In a review of outdoor transmission events, crowding } \\
\text { was a common factor among outbreaks, but circulation } \\
\text { (mixing) of participants, close range interactions with loud } \\
\text { conversations, shouting or singing and duration were } \\
\text { found to be important factors (Weed \& Foad). } \\
\text { A rapid synthesis by found that large clusters occurred in } \\
\text { settings where individuals were confined for prolonged } \\
\text { periods of time (e.g. shared accommodations, food } \\
\text { processing plants, religious services). }\end{array}$ & N/A & $(21,24,25)$ \\
\hline
\end{tabular}


Table 2: Criteria for evaluating transmission risk in settings (continued)

\begin{tabular}{|c|c|c|c|c|}
\hline Criteria & $\begin{array}{l}\text { Level (from lower to } \\
\text { higher risk) }\end{array}$ & Summary: What is known & Examples & References \\
\hline $\begin{array}{l}\text { Contact } \\
\text { between } \\
\text { participants } \\
\text { during activity }\end{array}$ & $\begin{array}{l}\text { 1. No physical contact } \\
\text { 2. Within } 2 \text { meter } \\
\text { 3. Some physical } \\
\text { contact, within } 1 \text { meter } \\
\text { of participants, sharing } \\
\text { of surfaces } \\
\text { 4. Close physical } \\
\text { contact, skin contact }\end{array}$ & $\begin{array}{l}\text { Transmission of SARS-CoV-2 is primarily via prolonged } \\
\text { close contact and exposure to respiratory secretions. } \\
\text { Close proximity contacts between individuals increases } \\
\text { the likelihood of transmission of virus with contact } \\
\text { interactions ranging from face-to-face interactions to } \\
\text { direct physical contact either. Transmission risk can be } \\
\text { mitigated to some extent by use of masks, and other PPE. } \\
\text { Workplace infections have been facilitated by close } \\
\text { contact and duration of interaction. For example, } \\
\text { grocery store employees with direct customer exposure, } \\
\text { paramedics and firefighters with physical contact with } \\
\text { potentially infected individuals at higher risk. }\end{array}$ & N/A & $(24,25)$ \\
\hline $\begin{array}{l}\text { Density of } \\
\text { crowd }\end{array}$ & $\begin{array}{l}\text { 1. Low (more than } \\
2 \text { meter distancing } \\
\text { regularly maintained) } \\
\text { 2. Medium ( } 2 \text { meter } \\
\text { distancing) } \\
\text { 3. High (less than } \\
2 \text { meter between } \\
\text { participants) }\end{array}$ & $\begin{array}{l}\text { Dalton et al. suggest an 8-fold increase in risk of viral } \\
\text { dose excretion and inhalation from communicating at a } \\
\text { distance of } 30 \mathrm{~cm} \text { vs } 1 \text { meter. } \\
\text { Settings where physical distancing at or around } 2 \text { meter } \\
\text { not possible linked with increased risk of transmission. }\end{array}$ & $\begin{array}{l}\text { Nightclubs with poor } \\
\text { ventilation, crowding } \\
\text { and loud music leading } \\
\text { to attendees potentially } \\
\text { yelling and leaning } \\
\text { very close together to } \\
\text { communicate; Karaoke } \\
\text { rooms }\end{array}$ & $(17,21)$ \\
\hline $\begin{array}{l}\text { Mixing of } \\
\text { networks/ } \\
\text { bubbles at } \\
\text { event (closed } \\
\text { small groups } \\
\text { vs random } \\
\text { participants } \\
\text { every time) }\end{array}$ & $\begin{array}{l}\text { 1. Closed small group } \\
\text { with no outside contacts } \\
\text { 2. Closed group with } \\
\text { some outside contacts } \\
\text { 3. Random mixing of } \\
\text { large groups }\end{array}$ & $\begin{array}{l}\text { From predictive modeling studies: } \\
\text { - Small closed community networks where groups of } \\
\text { people only interact with a chosen group of other } \\
\text { people and there is limited interaction outside network } \\
\text { have lower risk. Risk increases with bridges to other } \\
\text { networks. } \\
\text { - Random mixing events (e.g. public transport, bars and } \\
\text { sporting events) are higher risk because of mixing from } \\
\text { many small networks. } \\
\text { - Could also include settings where exposed to multiple } \\
\text { clients (for example transport workers, sales people, } \\
\text { cleaners). } \\
\text { A review of workplace related transmission risk found that } \\
\text { drivers and transport workers, service and sales workers, } \\
\text { food industry, personal care occupations, food production, } \\
\text { preschool occupations, community and social services, } \\
\text { construction and related trades occupations and public } \\
\text { safety workers were most at risk of infection (these groups } \\
\text { are highly exposed to random individuals/clients in their } \\
\text { line of work). }\end{array}$ & $\begin{array}{l}\text { Ski resorts due to their } \\
\text { attraction of global } \\
\text { travellers }\end{array}$ & $(26-28)$ \\
\hline $\begin{array}{l}\text { Mixing of } \\
\text { participants } \\
\text { (circulation } \\
\text { and mixing of } \\
\text { participants } \\
\text { within the } \\
\text { event) }\end{array}$ & $\begin{array}{l}\text { 1. None } \\
\text { 2. Moderate } \\
\text { 3. High }\end{array}$ & $\begin{array}{l}\text { In a review of outdoor transmission events, crowding } \\
\text { (number and density) was a common factor among } \\
\text { outbreaks, but circulation (mixing) of participants, close } \\
\text { range interactions with loud conversations, shouting or } \\
\text { singing and duration were important factors. }\end{array}$ & $\mathrm{N} / \mathrm{A}$ & $(21)$ \\
\hline
\end{tabular}


Table 2: Criteria for evaluating transmission risk in settings (continued)

\begin{tabular}{|c|c|c|c|c|}
\hline Criteria & $\begin{array}{l}\text { Level (from lower to } \\
\text { higher risk) }\end{array}$ & Summary: What is known & Examples & References \\
\hline $\begin{array}{l}\text { Number of } \\
\text { individuals } \\
\text { (per gathering } \\
\text { or event or } \\
\text { venue) }\end{array}$ & $\begin{array}{l}\text { 1. } 1 \\
\text { 2. } 1-2 \\
\text { 3. Less than } 5 \\
\text { 4. Less than } 10 \\
\text { 5. Less than } 100 \\
\text { 6. Less than } 1,000 \\
\text { 7. More than } 1,000\end{array}$ & $\begin{array}{l}\text { Large crowd size increases the probability that an infected } \\
\text { individual is present, increases crowding, contact and thus } \\
\text { transmission likelihood, even in outdoor settings. } \\
\text { Of fifty-five studies reviewed in recent PHAC evidence } \\
\text { brief, clear relationship found between increased } \\
\text { gathering size and risk, but size threshold was } \\
\text { inconsistent. When physical distancing breached, density } \\
\text { is high, circulation of participants occurs and gathering } \\
\text { takes place over extended duration of time, risk of } \\
\text { transmission increases. } \\
\text { An ecological study estimated a } 36 \% \text { reduction in } R_{\circ} \text { if } \\
\text { the cut-off for gathering size was } 10 \text { people, compared } \\
\text { to } 21 \% \text { if it was } 100 \text { people, and a } 2 \% \text { reduction in } R_{\circ} \\
\text { if the cut-off for gathering size was } 1,000 \text { people. In an } \\
\text { evaluation of NPls at a global scale, Esra et al. estimated } \\
\text { overall } 10 \% \text { reduction in infections associated with } \\
\text { gathering size restrictions. } \\
\text { In indoor environments in particular, larger numbers } \\
\text { of individuals increases the potential concentration of } \\
\text { airborne virus-carrying particles and number of individuals } \\
\text { that can be exposed at any given time. }\end{array}$ & $\begin{array}{l}\text { Carnival outbreak in } \\
\text { Germany with } 1,700 \\
\text { cases } \\
\text { Sporting events also } \\
\text { associated with outbreaks } \\
\text { Weddings, religious } \\
\text { gatherings, bars linked to } \\
\text { clusters in Hong Kong }\end{array}$ & $\begin{array}{l}(21,22,24 \\
29-33)\end{array}$ \\
\hline $\begin{array}{l}\text { Related activity } \\
\text { (e.g. shared/ } \\
\text { group travel to } \\
\text { setting) }\end{array}$ & $\begin{array}{l}\text { 1. None } \\
\text { 2. Yes, related activity } \\
\text { with transmission risk }\end{array}$ & $\begin{array}{l}\text { Congregate work and living increase the risk of } \\
\text { transmission. }\end{array}$ & $\mathrm{N} / \mathrm{A}$ & (34) \\
\hline $\begin{array}{l}\text { Ease of contact } \\
\text { tracing should } \\
\text { an outbreak } \\
\text { occur }\end{array}$ & $\begin{array}{l}\text { 1. Participants' details } \\
\text { available and can be } \\
\text { easily reached should } \\
\text { the need arise } \\
\text { 2. Inconsistent tracking } \\
\text { of participants may be } \\
\text { difficult to follow-up } \\
\text { 3. None }\end{array}$ & $\begin{array}{l}\text { Timely test, trace and isolation have been shown to } \\
\text { be important NPI strategies for working to contain } \\
\text { transmission of COVID-19. } \\
\text { Modelling studies show delays in tracing (three or more } \\
\text { days) fail to bring Rt under } 1 \text {. }\end{array}$ & $\mathrm{N} / \mathrm{A}$ & $(21,35,36)$ \\
\hline $\begin{array}{l}\text { Cohorting } \\
\text { and physical } \\
\text { distancing } \\
\text { to reduce } \\
\text { contacts }\end{array}$ & $\begin{array}{l}\text { 1. Cohorting to reduce } \\
\text { mixing of networks and } \\
\text { density/numbers } \\
\text { 2. None }\end{array}$ & $\begin{array}{l}\text { Successful prevention of transmission in the workplace } \\
\text { linked to limited physical contact, including cohorting or } \\
\text { staggering of employees. }\end{array}$ & $\mathrm{N} / \mathrm{A}$ & $(37,38)$ \\
\hline $\begin{array}{l}\text { Level of } \\
\text { expelled air }\end{array}$ & $\begin{array}{l}\text { 1. Silent } \\
\text { 2. Talking } \\
\text { 3. Singing or shouting } \\
\text { 4. Moderate to intense } \\
\text { physical exercise } \\
\text { 5. Aerosol-forming } \\
\text { medical procedures }\end{array}$ & $\begin{array}{l}\text { Dalton et al. suggest a } 3 \text { to } 10 \text {-fold increase in risk of } \\
\text { viral dose excretion due to louder vocalization (yelling or } \\
\text { singing) in environments with loud music. } \\
\text { Dalton et al. further suggest a } 3 \text {-fold increase in risk of } \\
\text { viral dose excretion due to light exercise (compared to } \\
\text { talking). }\end{array}$ & $\begin{array}{l}\text { Example of transmission } \\
\text { in singing group/choir } \\
\text { Gyms }\end{array}$ & $(17,39-45)$ \\
\hline $\begin{array}{l}\text { Age structure } \\
\text { of the } \\
\text { participant } \\
\text { population }\end{array}$ & $\begin{array}{l}\text { 1. Low risk-mostly } \\
\text { children } \\
\text { 2. Medium risk-mixed } \\
\text { adults and children } \\
\text { 3. High risk-all adults }\end{array}$ & $\begin{array}{l}\text { Analysis of data from Wuhan found greatest model fit } \\
\text { for testing of hypothesis that children show more mild } \\
\text { symptoms. } \\
\text { Infection fatality rate estimates close to zero for children } \\
\text { and younger adults and rise exponentially with age. }\end{array}$ & $\mathrm{N} / \mathrm{A}$ & $(46-49)$ \\
\hline $\begin{array}{l}\text { Environmental } \\
\text { cleaning/other } \\
\text { transmission } \\
\text { mitigation } \\
\text { efforts }\end{array}$ & $\begin{array}{l}\text { 1. Yes, use of } \\
\text { plexiglass or other } \\
\text { non-permeable barrier } \\
\text { between individuals; } \\
\text { hand washing and } \\
\text { consistent cleaning } \\
\text { of shared surface and } \\
\text { environment after every } \\
\text { individual use } \\
\text { 2. None }\end{array}$ & $\begin{array}{l}\text { Public health interventions most effective when combined. } \\
\text { Modelling shows hand hygiene, use of masks, and limiting } \\
\text { individual contacts help to reduce transmission in larger } \\
\text { gatherings of random individuals. }\end{array}$ & N/A & (26) \\
\hline
\end{tabular}


Table 2: Criteria for evaluating transmission risk in settings (continued)

\begin{tabular}{|c|c|c|c|c|}
\hline Criteria & $\begin{array}{l}\text { Level (from lower to } \\
\text { higher risk) }\end{array}$ & Summary: What is known & Examples & References \\
\hline $\begin{array}{l}\text { Use of masks } \\
\text { or face } \\
\text { coverings }\end{array}$ & $\begin{array}{l}\text { 1. Masks or face } \\
\text { coverings consistently } \\
\text { used properly } \\
\text { 2. Masks or face } \\
\text { coverings poorly used } \\
\text { 3. No masks nor face } \\
\text { coverings worn }\end{array}$ & $\begin{array}{l}\text { Much of the research on use of face masks was done prior } \\
\text { to COVID-19 and the use of surgical masks. Observational } \\
\text { studies on the use of protective effects of face masks } \\
\text { against influenza like illness have been demonstrated. } \\
\text { Studies on healthcare worker use of non-medical masks } \\
\text { has demonstrated protection compared to no mask. } \\
\text { Modelling shows hand hygiene, use of masks, and limiting } \\
\text { individual contacts help to reduce transmission in larger } \\
\text { gatherings of random individuals }\end{array}$ & $\begin{array}{l}\text { Shared transport by bus } \\
\text { example in China where } \\
\text { infected traveller wore no } \\
\text { mask during first bus ride } \\
\text { and infected five other } \\
\text { travellers, but wore mask } \\
\text { during second bus ride } \\
\text { with no secondary cases } \\
\text { arising from last trip (Liu } \\
\text { \& Zhang) }\end{array}$ & $(26,50,51)$ \\
\hline $\begin{array}{l}\text { Shared } \\
\text { equipment or } \\
\text { surfaces }\end{array}$ & $\begin{array}{l}\text { 1. None } \\
\text { 2. Some shared } \\
\text { equipment or surfaces } \\
\text { but disinfected regularly } \\
\text { 3. Some shared surfaces } \\
\text { (e.g. elevator buttons, } \\
\text { door handles, pens), } \\
\text { individuals encouraged } \\
\text { to disinfect self before } \\
\text { use } \\
\text { 4. Activity entails } \\
\text { shared equipment and } \\
\text { surfaces that cannot be } \\
\text { disinfected continuously } \\
\text { for practical reasons }\end{array}$ & $\begin{array}{l}\text { Transmission of SARS-CoV-2 is primarily via prolonged } \\
\text { close contact and exposure to respiratory secretions. } \\
\text { However, SARS-CoV-2 can survive on various surfaces for } \\
\text { limited amounts of time. Fomite transmission is known } \\
\text { to occur with MERS-CoV and SARS. SARS-CoV-2 virus } \\
\text { survival shown to be dependent on relative humidity and } \\
\text { nature of contact surface (survival likelihood greater on } \\
\text { plastic and stainless steel versus copper or cardboard } \\
\text { surfaces). Transmission via contaminated surfaces appears } \\
\text { possible. } \\
\text { Environmental samples taken from an infected patient's } \\
\text { room (door handle, toilet bowl, sink, air outlet fans) in } \\
\text { Singapore found to be positive for SARS-CoV-2. Two other } \\
\text { infected patient's room samples all negative. First patient } \\
\text { had higher viral load than later two. Tests did not assess } \\
\text { virus viability from samples. }\end{array}$ & $\begin{array}{l}\text { Religious gatherings can } \\
\text { present opportunities to } \\
\text { pass around offerings, } \\
\text { sacramental objects } \\
\text { or sharing of food and } \\
\text { refreshments. Outbreaks } \\
\text { reported in South Korea } \\
\text { and Arkansas, United } \\
\text { States. Note that singing, } \\
\text { indoor facility and } \\
\text { ventilation also described } \\
\text { as having taken place in } \\
\text { Arkansas outbreak }\end{array}$ & $(17,52-54)$ \\
\hline
\end{tabular}

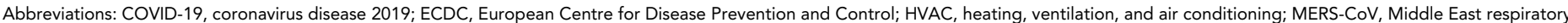
syndrome coronavirus; N/A, not applicable; NPI, non-pharmaceutical interventions; PHAC, Public Health Agency of Canada; PPE, personal protective equipment; R, reproduction number; SARS, severe acute respiratory syndrome; SARS-CoV-2, severe acute respiratory syndrome coronavirus

\section{Results}

Fifteen characteristics (i.e. criteria) were presented to a set of experts for ranking from highest to lowest level of importance when evaluating transmission risk of COVID-19 in various settings. Fifteen experts returned rankings by the deadline, and while the number of respondents was low, the respondents represented the geographic regions in Canada most affected by COVID-19 at the time.

\section{Consensus ranking by means of generalized Mallows models}

A generally good consensus emerged among experts on the relative importance of the criteria with some individual variations in specific ranking positions (Figure 1). Table 3 shows the rankings created by each participant. The consensus ranking resulting from the generalized Mallows models with the Kendall and Hamming distance is shown in Table 4. While there was broad agreement between the two consensus rankings, differences emerged as a result of wider variation in respondent rankings for some criteria.
Figure 1: Rank cross-entropy and Hamming theta ${ }^{\text {a }}$ from the generalized Mallows model ${ }^{\mathrm{b}}$

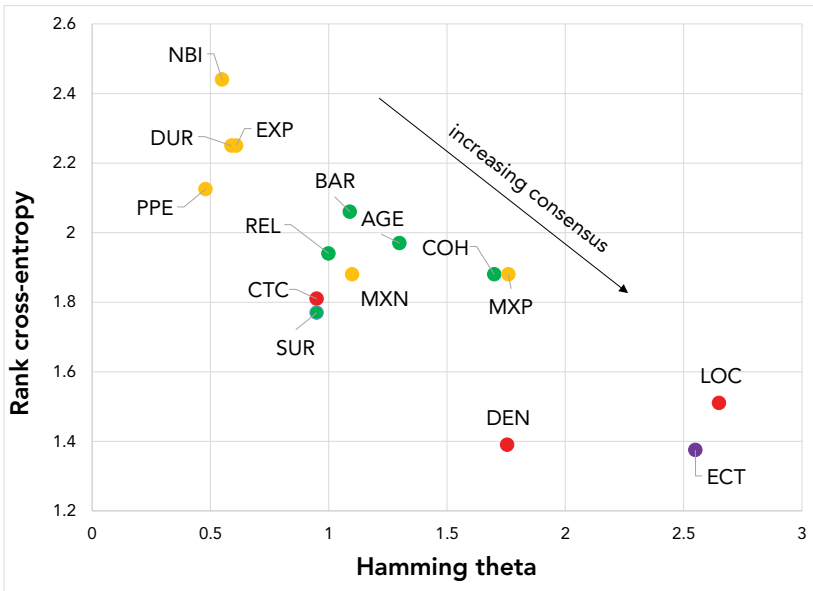

Abbreviations: AGE, age structure of participants; BAR, engineering controls—use of physical barriers and environmental cleaning; CTC, contact between participants; $\mathrm{COH}$, use of cohorting; DEN, density of crowd; DUR, duration of event; ECT, ease of contact tracing; EXP level of expelled air: LOC, location and ventilation; $M X N$, mixing of networks; MXP, mixing of participants; NBI, number of households; PPE, personal protective equipment; REL, related activity; SUR, shared equipment or surfaces activity; SUR, shared equip

${ }^{b}$ Criteria are color coded by category: critical criteria in red, important criteria in orange, good to consider criteria in green and if time permits criterion in purple. Consensus among respondents on the absolute ranking positions of criteria increases for criteria located in the lower right quadrant 
Table 3: Expert rankings of COVID-19 transmission criteria ${ }^{a}$

\begin{tabular}{|c|c|c|c|c|c|c|c|c|c|c|c|c|c|c|c|}
\hline \multirow{2}{*}{ Expert } & \multicolumn{15}{|c|}{ Criteria ranking } \\
\hline & 1 & 2 & 3 & 4 & 5 & 6 & 7 & 8 & 9 & 10 & 11 & 12 & 13 & 14 & 15 \\
\hline 1 & LOC & DUR & СТC & DEN & MXN & MXP & $\mathrm{NBI}$ & REL & ECT & $\mathrm{COH}$ & EXP & AGE & BAR & PPE & SUR \\
\hline 2 & LOC & AGE & СТC & MXN & $\mathrm{NBI}$ & MXP & EXP & ECT & SUR & PPE & DUR & REL & BAR & DEN & $\mathrm{COH}$ \\
\hline 3 & LOC & ECT & EXP & DUR & $\mathrm{NBI}$ & REL & СТC & SUR & AGE & $\mathrm{COH}$ & MXN & MXP & PPE & DEN & BAR \\
\hline 4 & AGE & MXP & LOC & DUR & EXP & $\mathrm{COH}$ & СТC & ECT & SUR & BAR & $\mathrm{NBI}$ & REL & MXN & DEN & PPE \\
\hline 5 & MXN & СТC & $\mathrm{NBI}$ & DUR & REL & DEN & LOC & AGE & SUR & BAR & ECT & PPE & $\mathrm{COH}$ & MXP & EXP \\
\hline 6 & $\mathrm{NBI}$ & DEN & DUR & LOC & MXN & MXP & ECT & REL & PPE & BAR & $\mathrm{COH}$ & SUR & EXP & СТC & AGE \\
\hline 7 & MXP & MXN & LOC & DUR & ECT & REL & DEN & SUR & EXP & $\mathrm{COH}$ & СТC & AGE & PPE & $\mathrm{NBI}$ & BAR \\
\hline 8 & MXP & NBI & DUR & LOC & ECT & DEN & MXN & СTC & BAR & AGE & REL & EXP & PPE & SUR & $\mathrm{COH}$ \\
\hline 9 & $\mathrm{COH}$ & DEN & LOC & DUR & MXP & MXN & REL & $\mathrm{NBI}$ & SUR & BAR & СТC & EXP & AGE & PPE & ECT \\
\hline 10 & СТC & DUR & MXN & LOC & REL & $\mathrm{NBI}$ & MXP & ECT & SUR & BAR & DEN & PPE & AGE & $\mathrm{COH}$ & EXP \\
\hline 11 & LOC & EXP & $\mathrm{NBI}$ & DEN & ECT & REL & $\mathrm{COH}$ & PPE & AGE & СТC & MXP & SUR & DUR & MXN & BAR \\
\hline 12 & LOC & $\mathrm{NBI}$ & СТC & DEN & MXN & EXP & DUR & AGE & SUR & ECT & REL & PPE & MXP & $\mathrm{COH}$ & BAR \\
\hline 13 & LOC & EXP & MXP & СТC & $\mathrm{NBI}$ & REL & DEN & AGE & SUR & MXN & $\mathrm{COH}$ & PPE & ECT & DUR & BAR \\
\hline 14 & LOC & $\mathrm{COH}$ & DUR & СТC & BAR & REL & ECT & SUR & AGE & PPE & DEN & $\mathrm{NBI}$ & MXP & MXN & EXP \\
\hline 15 & LOC & MXP & DUR & DEN & REL & ECT & BAR & EXP & SUR & $\mathrm{NBI}$ & MXN & $\mathrm{COH}$ & AGE & СТС & PPE \\
\hline
\end{tabular}

Abbreviations: AGE, age structure of participants; BAR, engineering controls—use of physical barriers and environmental cleaning; $C T C$, contact between participants; $C O H$, use of cohorting; DEN, density of crowd; DUR, duration of event; ECT, ease of contact tracing; EXP, level of expelled air; LOC, location and ventilation; MXN, mixing of networks; MXP, mixing of participants; $\mathrm{NBI}$, number of households; PPE, personal protective equipment; REL, related activity; SUR, shared equipment or surfaces

${ }^{a}$ Responses correspond to individual expert rankings

Table 4: Consensus ranking (mode) of criteria under generalized Mallows models using the Kendall and Hamming distance

\begin{tabular}{|c|c|c|c|c|}
\hline Category & Code & Criteria & Kendall & Hamming \\
\hline \multirow[t]{3}{*}{ Critical } & DEN & Density of crowd & 1 & 2 \\
\hline & CTC & Contact between participants & 2 & 3 \\
\hline & LOC & Location and ventilation & 3 & 1 \\
\hline \multirow[t]{6}{*}{ Important } & $\mathrm{NBI}$ & Number of households (or individuals) & 4 & 4 \\
\hline & EXP & Level of expelled air (of activity) & 5 & 10 \\
\hline & DUR & Duration of event & 6 & 6 \\
\hline & PPE & Personal protective equipment-use of masks or face coverings & 7 & 5 \\
\hline & MXP & Mixing of participants & 8 & 8 \\
\hline & MXN & Mixing of networks & 9 & 7 \\
\hline \multirow{5}{*}{$\begin{array}{l}\text { Good to } \\
\text { consider }\end{array}$} & BAR & Engineering controls-use of physical barriers and environmental cleaning & 10 & 12 \\
\hline & REL & Related activity (e.g. shared group travel) & 11 & 9 \\
\hline & $\mathrm{COH}$ & Administrative scheduling-use of cohorting to stagger participants and reduce contacts & 12 & 13 \\
\hline & AGE & Age structure of participants in population & 13 & 14 \\
\hline & SUR & Shared equipment or surfaces & 14 & 11 \\
\hline If time permits & ECT & Ease of contact tracing should an outbreak occur & 15 & 15 \\
\hline
\end{tabular}

Abbreviations: AGE, age structure of participants; BAR, engineering controls-use of physical barriers and environmental cleaning; CTC, contact between participants; $\mathrm{COH}$, use of cohorting; DEN, density of crowd; DUR, duration of event; ECT, ease of contact tracing; EXP, level of expelled air; LOC, location and ventilation; MXN, mixing of networks; MXP, mixing of participants;

$\mathrm{NBI}$, number of households; PPE, personal protective equipment; REL, related activity; SUR, shared equipment or surfaces 
Location and ventilation and ease of contact tracing were the criteria on which experts most strongly agreed in terms of absolute rank ordering (i.e. most important and least important criteria). Location and ventilation appears exclusively in the first seven ranks and almost always ( $n=14 / 15$ times) in the first four ranks. Criteria with stronger disagreement among experts regarding absolute rank position were number of households or individuals and level of expelled air.

\section{Criteria categorization based on combined consensus rankings}

Criteria were placed into categories based on their level of agreement between experts and combined Kendall and Hamming rank orderings (Table 4). Four categories were created as a result of these ranking agreements among experts: "critical"; "important"; "good to consider"; and "if time permits".

\section{Categories 1 and 2: Critical and important criteria}

The first set of criteria ("critical") consisted of three criteria that were consistently ranked within the first few positions by experts: 1) density of the crowd; 2) contact between participants; and 3) location and ventilation.

The second set of criteria ("important") were almost consistently ranked within the top half of the ranking by experts (with the exception of level of expelled air), though some variability in specific rank positioning was observed among experts: 1) number of households; 2) level of expelled air (of activity); 3 ) duration of the event or activity; 4) use of personal protective equipment; 5) mixing of networks; and 6) mixing of participants. While level of expelled air showed wide variation in expert ranking (present in the top half for some experts and the bottom half for others); given available literature data on this criterion, it was placed in the "important" category.

\section{Categories 3 and 4: Good to consider and if time permits criteria}

The third set ("good to consider") consisted of five criteria. Experts generally ranked these criteria in the lower half of their rankings, though relative importance attributed to each criteria varied between experts. This set included the following: 1) the use of engineering controls and environmental cleaning; 2) related activity; 3 ) administrative scheduling; 4) age structure of participants; and 5) shared equipment or surfaces. Finally, given very strong agreement for the rank positioning of the last criterion, ease of contact tracing, which was almost consistently ranked last among experts, this criterion was placed in the "if time permits" category.

\section{Discussion}

This project aimed to identify key factors (criteria) to consider when making decisions around COVID-19 transmission risk in various settings where people gather. The use of generalized Mallows models allowed for the analysis and quantification of the consensus among experts on the rank importance of different transmission risk factors (criteria). A lack of approximate consensus on a given criterion can lead to large differences between models with different metrics; however, using the Kendall and Hamming metrics, broad consensus was found among the most important and least important criteria.

The consensus-ranked list of transmission criteria and corresponding categories resulting from this exercise contribute to a framework for ranking settings for COVID-19 transmission risk based on criteria identified from both the literature and expert opinion. How a setting is evaluated or scored with respect to a specific criterion will depend on a range of factors specific to the local community where the evaluation is undertaken, including local transmission, public health measures in place, current adoption of those measures by the local population and setting-specific characteristics.

Although this framework is intended to assist in evaluating transmission risk, all risk assessments should be performed in the context of the local epidemiology and with consideration of the specific characteristics of the gathering/event/venue being evaluated. A ranking of transmission risk of settings produced in one geographical location will not necessarily be the same as that performed in another geographical location due to local epidemiological variation even if the same criteria are used.

Based on the formative research conducted, the consensus list captures elements that are most directly related to transmission risk. When evaluating settings and their risk for transmission, it is important to keep in mind the activities performed on site and their related contexts since related activities may affect transmission risk; e.g. shared transport to the setting or shared accommodations. These related activities may present additional opportunities for transmission that may be important to consider for inclusion in the risk assessment.

Many of the criteria presented are inter-related or synergistic and, as a result, may be difficult to evaluate individually (e.g. the number of participants at an event and the density of the crowd). The use of scenarios may help tease apart some of these factors. For example, a scenario could be defined to evaluate transmission risk when a certain percentage of the population is vaccinated, and a separate scenario defined to consider a different target vaccination percentage. Alternate scenarios could be defined to consider different levels of community transmission as local prevalence of COVID-19 will change the likelihood of encountering an infected individual. Expert review 
and discussion of the evaluations is also important as it will promote cross-examination and consideration of a broad set of local factors.

Operationalization of this list and resulting categories is left to the discretion of regional public health experts, though some suggestions are discussed. Assessment as part of a multi-step MCDA process would enable a systematic evaluation between settings; however, a full illustration of this approach is beyond the scope of this article.

\section{Variant of concern considerations}

Transmission risk evaluation will continue to be necessary until sufficient vaccination coverage can be reached to achieve herd immunity. With the emergence of VOCs across the country, additional waves of cases may continue to threaten healthcare capacity in Canada despite vaccine rollout. As such, our experts were consulted once again in March 2021 to see if their rankings of the criteria would change given the emergence of VOCs. Given a lack of evidence that VOCs affect transmission risk differently, the experts that responded $(n=10 / 15)$ left their rankings unchanged. This should be monitored as further knowledge is gathered on the subject.

\section{Using the criteria for evaluation of settings and gatherings and limitations}

Although a full multi-criteria evaluation of settings is outside of the scope of the current paper, some guidelines on the use of the criteria for evaluating settings are suggested below. Software packages exist for MCDA analysis, including a recently developed free package for $\mathrm{R}$ (https://cran.r-project. org/web/packages/MCDA/MCDA.pdf) and other academic or paid software options. These software packages allow MCDA analysis without the need for statistical experts to carry out the evaluations.

Before undertaking an evaluation of settings, the scope and scale of the assessment should be clearly defined. For example, it is important to define whether the evaluation is being performed to assess the daily exposure of individuals to transmission at any given setting versus assessment of the daily exposure of individuals working all day at a setting since a setting may pose different risks to a casual visitor versus an employee who is exposed over several hours. It is important to consider whether specific subgroups are to be considered in the assessment; for example, are clinically-vulnerable individuals included in the scope or is a separate assessment required to properly assess this subgroup? As settings are considered for inclusion, creating a description of the setting in the context being assessed is useful (e.g. in a grocery store-where a typical visit generally lasts approximately 15 minutes_masks are currently mandatory). Additional variations of settings can be added to assess variations that may be relevant to consider (e.g. variations where mask use is not mandatory, etc.). A quick review of the criteria should be undertaken by the experts participating in the process to assess whether all proposed criteria remain relevant to the local context (e.g. a criterion for which all settings have the same score is not discriminating and may be omitted from the evaluation).

Depending on the data available to a decision-maker for assessing settings, and taking into account levels of uncertainty, variability and missing data, the essential and important criteria should be evaluated where possible as a first level of assessment of COVID-19 transmission risk between settings. Expert judgement and opinion can be used to fill in missing data. If sufficient information is available or can be appropriately assessed by experts, a more complete MCDA-style assessment of settings can be undertaken. A systematic evaluation process, such as offered by an MCDA evaluation, can be used to better understand the relative transmission risk between settings and, in particular, to highlight the strongest contributing factors as well as strongest protective factors for transmission risk between settings. This type of evaluation could help inform where mitigation measures should be considered to help reduce transmission risk. A setting that has criteria that score as poor or insufficient should be considered for mitigation and potential monitoring of transmission risk. As previously suggested, the use of scenarios can also be used to consider the changing epidemiology and its impact on transmission. For example, scenarios with different levels of vaccination, new levels of dominance of a VOC and levels of community transmission can be defined and used to evaluate how they may affect relative transmission risk of settings.

Depending on the data available and levels of uncertainty around these data, any resulting ranking will not represent a strict absolute assessment or ranking of settings, but rather a working local evaluation that reflects the information available and the relevant experts participating in the process.

As a reminder, the use of this framework is meant to help inform decision-making around transmission risk rather than make decisions, since other factors should be considered in a decision-making process around closures. To conduct a more complete assessment of closures/re-openings, additional dimensions beyond transmission risk factors alone such as social considerations, economic and other health factors could be considered for inclusion in a multi-step participatory MCDA process.

\section{Conclusion}

This project drew upon the latest evidence concerning transmission risk factors for COVID-19 in venues from which criteria for the evaluation of transmission risk was developed and then evaluated by experts. The resulting consensus list constitutes a set of important generic elements that can be applied to any setting as an objective and transparent framework to assess transmission risk in the venue. With further 
consideration of the local epidemiology of COVID-19, an overall risk of transmission assessment can be established. This work focused on the factors most directly related to COVID-19 transmission as a first level of concern in evaluating settings. Depending on the decision-making context (e.g. decisions around closures or re-openings) additional factors should be considered for inclusion in the decision-making process, including economic and social impacts. Additional layers of information could be added to the participatory MCDA process to include economic, social and health criteria so that tradeoffs could be more fully examined, allowing for more informed decisions by decision-makers around closures and re-openings to reduce the transmission risk of COVID-19.

\section{Authors' statement}

$\mathrm{VH}$ - Conception and design, data acquisition and interpretation, writing-original draft, review and editing DM \& JL - Data acquisition, data analysis, writing-review and editing

AF, AO, PT and $\mathrm{NHO}$ - Conception and design, revising and editing of writing and critical review

LW - Interpretation, revising and editing of writing and critical review

\section{Competing interests}

None.

\section{Acknowledgements}

The authors would like to thank members of the technical advisory group and the Canadian Pandemic Influenza

Preparedness (CPIP) task force for their support and feedback in this project; as well as the Knowledge Synthesis team members within Public Health Risk Sciences Division of Public Health Agency of Canada for their invaluable knowledge synthesis products. The authors would also like to thank members of the Communicable and Infectious Disease Steering Committee and modelling secretariat for logistical support with this project.

\section{Funding}

None.

\section{References}

1. World Health Organization. Novel coronavirus (2019-nCoV) Situation Report. Geneva, Switzerland: WHO; 21 January 2020 (accessed 2021-03-01). www.who.int/docs/defaultsource/coronaviruse/situation-reports/20200121-sitrep-12019-ncov.pdf
2. Government of Canada. COVID-19 daily epidemiology update. Ottawa (ON): Government of Canada; (updated 2021-09-15; accessed 2021-04-26). https://www.canada.ca/ en/public-health/services/diseases/2019-novel-coronavirusinfection/health-professionals/epidemiological-summarycovid-19-cases.html\#a4

3. Huang $C$, Wang $Y$, Li X, Ren $L$, Zhao J, Hu Y, Zhang L, Fan G, Xu J, Gu X, Cheng Z, Yu T, Xia J, Wei Y, Wu W, Xie X, Yin W, Li H, Liu M, Xiao Y, Gao H, Guo L, Xie J, Wang G, Jiang R, Gao Z, Jin Q, Wang J, Cao B. Clinical features of patients infected with 2019 novel coronavirus in Wuhan, China. Lancet 2020;395(10223):497-506. DOI PubMed

4. Detsky AS, Bogoch II. COVID-19 in Canada: experience and Response. JAMA 2020;324(8):743-4. DOI PubMed

5. Adams-Prassl A, Boneva T, Golin M, Rauh C. Inequality in the impact of the coronavirus shock: Evidence from real time surveys. J Public Econ 2020;189:104245. DOI

6. Blundell R, Costa Dias M, Joyce R, Xu X. COVID-19 and Inequalities. Fisc Stud 2020. DOI PubMed

7. Brodeur A, Gray D, Islam A, Bhuiyan S. A literature review of the economics of COVID-19. J Econ Surv 2021. DOI PubMed

8. Calderón-Larrañaga A, Dekhtyar S, Vetrano DL, Bellander T, Fratiglioni L. COVID-19: Risk accumulation among biologically and socially vulnerable older populations. Ageing Res Rev 2020;63:101149. DOI PubMed

9. Engzell $P$, Frey $A$, Verhagen MD. Learning inequality during the COVID-19 pandemic. 2020; SocArXiv ve4z7, Center for Open Science. https://osf.io/preprints/socarxiv/ve4z7/

10. Nicola M, Alsafi Z, Sohrabi C, Kerwan A, Al-Jabir A, losifidis C, Agha M, Agha R. The socio-economic implications of the coronavirus pandemic (COVID-19): A review. Int J Surg 2020;78:185-93. DOI PubMed

11. Rossi R, Socci V, Talevi D, Mensi S, Niolu C, Pacitti $F$ Di Marco A, Rossi A, Siracusano A, Di Lorenzo G. COVID-19 pandemic and lockdown measures impact on mental health among the general population in Italy. Front Psychiatry 2020;11:790. DOI PubMed

12. Serafini G, Parmigiani B, Amerio A, Aguglia A, Sher L, Amore M. The psychological impact of COVID-19 on the mental health in the general population. QJM 2020;113(8):531-7. DOI PubMed

13. Behzadian M, Kazemzadeh RB, Albadvi A, Aghdasi M. PROMETHEE: A comprehensive literature review on methodologies and applications. Eur J Oper Res 2010;200(1):198-215. DOI

14. Satterthwaite MA. Strategy-proofness and Arrow's conditions: existence and correspondence theorems for voting procedures and social welfare functions. J Econ Theory 1975;10(2):187-217. DOI

15. Fligner MA, Verducci JS. Distance based ranking models. J R Stat Soc B 1986;48(3):359-69. DOI 
16. Brandl M, Selb R, Seidl-Pillmeier S, Marosevic D, Buchholz U, Rehmet $\mathrm{S}$. Mass gathering events and undetected transmission of SARS-CoV-2 in vulnerable populations leading to an outbreak with high case fatality ratio in the district of Tirschenreuth, Germany. Epidemiol Infect 2020;148:e252. DOI PubMed

17. Dalton C, Katelaris A, Wilson N. Open with Care: Minimising COVID-19 Superspreading Settings in Australia. SSRN. June 22, 2020. DOI

18. European Centre for Disease Prevention and Control. COVID-19 clusters and outbreaks in occupational settings in the EU/EEA and the UK. Solna, Sweden. ECDC; (updated 2020-08-11). https://www.ecdc.europa.eu/en/publicationsdata/covid-19-clusters-and-outbreaks-occupational-settingseueea-and-uk

19. Liu Y, Eggo RM, Kucharski AJ. Secondary attack rate and superspreading events for SARS-CoV-2. Lancet 2020;395(10227):e47. DOI PubMed

20. Nishiura H, Oshitani $H$, Kobayashi T, Saito T, Sunagawa T, Mutsui T, Wakita T, MHLW COVID-19 Response Team, Suzuki M. Closed environments facilitate secondary transmission of coronavirus disease 2019 (COVID-19). medRxiv 2020.02.28.20029272. DOI

21. Weed M, Foad A. Rapid scoping review of evidence of outdoor transmission of COVID-19. medRxiv. 2020.09.04.20188417. DOI

22. Public Health Agency of Canada. National Collaborating Centre for Methods and Tools. Evidence Brief of Size of Gatherings and Characteristics of High Risk Transmission Events 2020. Ottawa (ON): PHAC; 2020. https://www.nccmt. ca/covid-19/covid-19-evidence-reviews/194

23. Lednicky JA, Lauzardo M, Fan ZH, Jutla A, Tilly TB, Gangwar M, Usmani M, Shankar SN, Mohamed K, Eiguren-Fernandez A, Stephenson CJ, Alam MM, Elbadry MA, Loeb JC, Subramaniam K, Waltzek TB, Cherabuddi K, Morris JG Jr, Wu CY. Viable SARS-CoV-2 in the air of a hospital room with COVID-19 patients. Int J Infect Dis 2020;100:476-82. DOI PubMed

24. Leclerc QJ, Fuller NM, Knight LE, Funk S, Knight GM; CMMID COVID-19 Working Group. What settings have been linked to SARS-CoV-2 transmission clusters? Wellcome Open Res 2020;5:83. DOI PubMed

25. Lakha F, Rudge JW, Holt H. Rapid synthesis of evidence on settings which have been associated with SARS-CoV-2 transmission clusters. 2020 (accessed 2020-12-05). https://superspreadingdatabase.github.io/Evidence_on_ clusters_final.pdf

26. Scott N, Palmer A, Delport D, Abeysuriya R, Stuart R, Kerr CC, Mistry D, Klein D, Sacks-Davis R, Heath K, Hainsworth S, Pedrana A, Stoove M, Wilson D, Hellard ME. Modelling the impact of reducing control measures on the COVID-19 pandemic in a low transmission setting. Med J Aust 2020;214(2):79-83. DOI PubMed
27. Sneppen K, Taylor RJ, Simonsen L. Impact of Superspreaders on dissemination and mitigation of COVID-19. medRxiv. 2020.05.17.20104745. DOI

28. Health Information and Quality Authority. Evidence summary on activities or settings associated with a higher risk of SARS-CoV-2 transmission. HIQA; 2020 (accessed 2021-03-15). https://www.hiqa.ie/sites/default/files/2020-11/ Evidence-summary-activities-and-settings-at-higher-risk.pdf

29. Adam DC, Wu P, Wong JY, Lau EH, Tsang TK, Cauchemez S, Leung GM, Cowling BJ. Clustering and superspreading potential of SARS-CoV-2 infections in Hong Kong. Nat Med 2020;26(11):1714-9. DOI PubMed

30. Brauner JM, Mindermann S, Sharma M, Johnston D, Salvatier J, Gavenciak T, Stephenson AB, Leech G, Altman G, Mikulik V, Norman AJ, Monrad JT, Besiroglu T, Ge $\mathrm{H}$, Hartwick MA, The YW, Chindelevitch L, Gal Y Kulveit J. The effectiveness of eight nonpharmaceutical interventions against COVID-19 in 41 countries. medRxiv. 2020.05.28.20116129. DOI

31. Esra RT, Jamesion L, Fox MP, Letswalo D, Ngcobo N, Mngadi S, Estill J, Meyer-Rath G, Keiser O. Evaluating the impact of non-pharmaceutical interventions for SARS-CoV-2 on a global scale. medRxiv. 2020.07.30.20164939. DOI

32. Morawska L, Tang JW, Bahnfleth W, Bluyssen PM, Boerstra A, Buonanno G, Cao J, Dancer S, Floto A, Franchimon F, Haworth C, Hogeling J, Isaxon C, Jimenez JL, Kurnitski J, Li Y, Loomans M, Marks G, Marr LC, Mazzarella L, Melikov AK, Miller S, Milton DK, Nazaroff W, Nielsen PV, Noakes C, Peccia J, Querol X, Sekhar C, Seppänen O, Tanabe SI, Tellier R, Tham KW, Wargocki P, Wierzbicka A, Yao M. How can airborne transmission of COVID-19 indoors be minimised? Environ Int 2020;142:105832. DOI PubMed

33. Walker A, Houwaart T, Wienemann T, Vasconcelos MK, Strelow D, Senff T, Hülse L, Adams $O$, Andree $M$, Hauka S, Feldt T, Jensen BE, Keitel V, Kindgen-Milles D, Timm J, Pfeffer K, Dilthey AT. Genetic structure of SARS-CoV-2 reflects clonal superspreading and multiple independent introduction events, North-Rhine Westphalia, Germany, February and March 2020. Euro Surveill 2020;25(22):2000746. DOl PubMed

34. Dyal JW, Grant MP, Broadwater K, Bjork A, Waltenburg MA, Gibbins JD, Hale C, Silver M, Fischer M, Steinberg J, Basler CA, Jacobs JR, Kennedy ED, Tomasi S, Trout D, Hornsby-Myers J, Oussayef NL, Delaney LJ, Patel K, Shetty V, Kline KE, Schroeder B, Herlihy RK, House J, Jervis R, Clayton JL, Ortbahn D, Austin C, Berl E, Moore Z, Buss BF, Stover D, Westergaard R, Pray I, DeBolt M, Person A, Gabel J, Kittle TS, Hendren P, Rhea C, Holsinger C, Dunn J, Turabelidze G, Ahmed FS, deFijter S, Pedati CS, Rattay K, Smith EE, Luna-Pinto C, Cooley LA, Saydah S, Preacely ND, Maddox RA, Lundeen E, Goodwin B, Karpathy SE, Griffing S, Jenkins MM, Lowry G, Schwarz RD, Yoder J, Peacock G, Walke HT, Rose DA, Honein MA. COVID-19 among workers in meat and poultry processing facilities-19 states, April 2020. MMWR Morb Mortal Wkly Rep 2020;69(18):557-61. DOI PubMed 
35. Kucharski AJ, Klepac P, Conlan AJ, Kissler SM, Tang ML, Fry H, Gog JR, Edmunds WJ; CMMID COVID-19 working group. Effectiveness of isolation, testing, contact tracing, and physical distancing on reducing transmission of SARS-CoV-2 in different settings: a mathematical modelling study. Lancet Infect Dis 2020;20(10):1151-60. DOI PubMed

36. Kretzschmar ME, Rozhnova G, Bootsma MC, van Boven M, van de Wijgert JH, Bonten MJ. Impact of delays on effectiveness of contact tracing strategies for COVID-19: A modelling study. Lancet Public Health 2020;5(8):e452-9. DOI PubMed

37. Shaw AK, White LA, Michalska-Smith M, Borer ET, Craft ME, Seabloom EW, Snell-Rood EC, Travisano M. Lessons from movement ecology for the return to work: modeling contacts and the spread of COVID-19. PLoS One 2021;16(1):e0242955. DOI PubMed

38. Rafeemanesh E, Ahmadi F, Memarzadeh M. A review of the strategies and studies on the prevention and control of the new coronavirus in workplaces. Arch Bone Jt Surg 2020;8 (Suppl1):242-6. DOI PubMed

39. Charlotte N. High rate of SARS-CoV-2 transmission due to choir practice in France at the beginning of the COVID-19 pandemic. J Voice 2020;S0892-1997(20)30452-5. Epub ahead of print. DOI PubMed

40. Prakash MK. Eat, Pray, Work: A meta-analysis of COVID-19 Transmission Risk in Common Activities of Work and Leisure. medRxiv. 2020.05.22.20110726. DOI

41. Hamner L, Dubbel $P$, Capron I, Ross A, Jordan A, Lee J, Lynn J, Ball A, Narwal S, Russell S, Patrick D, Leibrand H. High SARS-CoV-2 attack rate following exposure at a choir practice-Skagit County, Washington, March 2020. MMWR Morb Mortal Wkly Rep 2020;69(19):606-10. DOI PubMed

42. Kohanski MA, Lo LJ, Waring MS. Review of indoor aerosol generation, transport, and control in the context of COVID-19. Int Forum Allergy Rhinol 2020;10(10):1173-9. DOI PubMed

43. Public Health Agency of Canada. National Collaborating Centre for Methods and Tools. Rapid Review on SARS-CoV-2 Aerosol Transmission, Update 2. Ottawa (ON): PHAC; 2021. https://www.nccmt.ca/covid-19/covid-19-evidencereviews/418

44. Moritz S, Gottschick C, Horn J, Popp M, Langer S, Klee B, Purschke O, Gekle M, Ihling A, Mikolajczyk R. The risk of indoor sports and culture events for the transmission of COCID-19 (Restart-19). medRxiv. 2020.10.28.20221580. DOI

45. Miller SL, Nazaroff WW, Jimenez JL, Boerstra A, Buonanno G, Dancer SJ, Kurnitski J, Marr LC, Morawska L, Noakes C. Transmission of SARS-CoV-2 by inhalation of respiratory aerosol in the Skagit Valley Chorale superspreading event. Indoor Air 2021;31(2):314-23. DOI PubMed

46. Davies NG, Klepac P, Liu Y, Prem K, Jit M, Eggo RM; CMMID COVID-19 working group. Age-dependent effects in the transmission and control of COVID-19 epidemics. Nat Med 2020;26(8):1205-11. DOI PubMed
47. Levin AT, Hanage WP, Owusu-Boaitey N, Cochran KB, Walsh SP, Meyerowitz-Katz G. Assessing the age specificity of infection fatality rates for COVID-19: systematic review, meta-analysis, and public policy implications. Eur J Epidemiol 2020;35(12):1123-38. DOI PubMed

48. Kang SJ, Jung SI. Age-related morbidity and mortality among patients with COVID-19. Infect Chemother 2020;52(2):154-64. DOI PubMed

49. Kim L, Garg S, O'Halloran A, Whitaker M, Pham H, Anderson EJ, Armistead I, Bennett NM, Billing L, Como-Sabetti K, Hill M, Kim S, Monroe ML, Muse A, Reingold AL, Schaffner W, Sutton M, Talbot HK, Torres SM, Yousey-Hindes $K$, Holstein R, Cummings C, Brammer L, Hall AJ, Fry AM, Langley GE. Risk factors for intensive care unit admission and in-hospital mortality among hospitalized adults identified through the US coronavirus disease 2019 (COVID-19)-associated hospitalization surveillance network (COVID-NET). Clin Infect Dis 2021;72(9):e206-14. DOl PubMed

50. Liu X, Zhang S. COVID-19: face masks and human-tohuman transmission. Influenza Other Respir Viruses 2020;14(4):472-3. DOl PubMed

51. Public Health Agency of Canada. National Collaborating Centre for Methods and Tools. Evidence Brief on the use of Face Masks to Prevent COVID-19 in Community Settings. Ottawa (ON): PHAC; 2020 (accessed 2020-12-05). https:// www.nccmt.ca/covid-19/covid-19-evidence-reviews/246

52. van Doremalen N, Bushmaker T, Morris DH, Holbrook MG, Gamble A, Williamson BN, Tamin A, Harcourt JL, Thornburg NJ, Gerber SI, Lloyd-Smith JO, de Wit E, Munster VJ. Aerosol and surface stability of SARS-CoV-2 as compared with SARS-CoV-1. N Engl J Med 2020;382(16):1564-7. DOl PubMed

53. James A, Eagle L, Phillips C, Hedges DS, Bodenhamer C, Brown R, Wheeler JG, Kirking H. High COVID-19 attack rate among attendees at events at a church-Arkansas, March 2020. MMWR Morb Mortal Wkly Rep 2020;69(20):632-5. DOI PubMed

54. Ong SW, Tan YK, Chia PY, Lee TH, Ng OT, Wong MS, Marimuthu K. Air, surface environmental, and personal protective equipment contamination by severe acute respiratory syndrome coronavirus 2 (SARS-CoV-2) from a symptomatic patient. JAMA 2020;323(16):1610-2. DOI PubMed

55. Arrow KJ. A difficulty in the concept of social welfare. J Polit Econ 1950;58(4):328-46. DOI

56. Gibbard A. Manipulation of voting schemes: a general result. Econom Soc. 1973;41(4):587-601. https://www.jstor.org/stable/1914083

57. Mallows CL. Non-null ranking models. I. Biometrika 1957;44(1/2):114-30. DOI 


\section{Appendix}

\section{A1: Rank orderings and generalized Mallows models}

Imagine that we have a set of $N$ rankings over $n$ choices. In our case, $N$ represents the number of experts and $n$ denotes the criteria (items). The problem is to find the consensus ranking among the experts, which best agrees with the $N$ rankings offered by the experts.

Consensus ranking finds application in social welfare analysis. In 1950, Kenneth Arrow showed (55) that if a decision-making body consists of at least two members with at least three options to decide among, then it is impossible to design a social welfare function that simultaneously satisfies all the reasonable requirements of a fair system:

- If every voter prefers alternative $X$ over alternative $Y$, then the group prefers $X$ over $Y$

- If every voter's preference between $X$ and $Y$ remains unchanged, then the group's preference between $X$ and $Y$ will also remain unchanged (even if voters' preferences between other pairs like $X$ and $Z, Y$ and $Z$, or $Z$ and $W$ change)

- There is no dictator: no single voter possesses the power to always determine the group's preference

Arrow's impossibility theorem has several technical conditions in its formal statement (see section A3) which defines the "fair" system. While the theorem tells us that no deterministic preferential voting system exists which satisfies the technical fairness requirements, in practice all systems do not work poorly at all times. The impossibility theorem finds application in the study of voting systems and important results can be found in $(14,56)$.

Rankings consist of bijections of the set of integers $\{1,2,3, \ldots, n\}$ onto themselves. We will denote rankings with the symbols $\pi$ and $\sigma$. For example, the ranking $\pi=\{2,4,1,3\}$ means that item 1 is ranked second, which we denote as $\pi(1)=2$; item two is ranked fourth, $\pi(2)=4$. Every ranking has an inverse $\pi^{-1}$ which gives the items in terms of the ranks: $\pi \cdot \pi^{-1}=e=\{1,2,3, \ldots, n\}$. Given a set of rankings, we would like to find the center or the consensus of the set over some distance measure between rankings. There are many distance metric for rankings, but in this article we will focus on two of the most popular: the Kendall distance and the Hamming distance. For any distance measure $d(\cdot, \cdot)$ we have $d(\sigma, \pi)=d\left(\sigma \pi^{-1}, e\right)$. When the reference ranking is the identity ranking $e$, we use the notion $d(\sigma, e)=d(\sigma)$.
The Kendall distance between two ranking $\pi$ and $\sigma$ is defined by,

Equation 1:

$$
d_{k}(\pi, \sigma)=\sum_{\substack{l<j \\ \pi}} 1[j \underset{\sigma}{\prec} l]
$$

The notation $l \prec_{\pi} j$ means that item $l$ precedes $j$ in ranking $\pi$. The Kendall distance counts the number of pairwise discrepancies between rankings. With $n$ items, the largest Kendall distance between any two rankings is $n(n-1) / 2$. On the other hand, the Hamming distance $d_{h}(\pi, \sigma)$ counts the number of positions that disagree between two rankings,

Equation 2:

$$
d_{k}(\pi, \sigma)=\sum_{j=1}^{n} 1[\pi(j) \neq \sigma(j)]
$$

Thus, the Hamming distance takes values between 2 and $n$ inclusively. The Kendall and Hamming distance measures have the important property that they can be decomposed as a sum over $n-1$ and $n$ terms respectively,

$$
\begin{aligned}
& \text { Equation } 3 \\
& \qquad \begin{array}{l}
d_{k}(\pi, \sigma)=\sum_{j=1}^{n-1} V_{j}\left(\pi \sigma^{-1}\right), \\
d_{h}(\pi, \sigma)=\sum_{j=1}^{n} H_{j}\left(\pi \sigma^{-1}\right),
\end{array}
\end{aligned}
$$

where,

Equation 4:

$$
V_{j}(\sigma)=\sum_{l>j} 1[l<j],
$$

Equation 5:

$$
H_{j}(\sigma)=\left\{\begin{array}{l}
0, \text { iff } \sigma(j)=\mathrm{j}, \\
1, \text { otherwise }
\end{array}\right.
$$


Given a metric for computing distances between rankings, we can build a probability measure over the space. Mallows model (14) is an exponential location probability model over the rankings defined by a central ranking, $\sigma_{0}$, and a dispersion parameter, $\theta$, namely,

Equation 6:

$$
P(\pi)=\frac{e^{-\theta d_{k, h}\left(\pi, \sigma_{0}\right)}}{\psi(\theta)}
$$

where $\psi(\theta)$ is a normalization constant. In a sense, the Mallows model is the extension of the Gaussian distribution to rankings. When $\theta>0$, the ranking $\sigma_{0}$ is the mode of the distribution-the consensus-and as $\theta$ increases the distribution becomes more sharply peaked around $\sigma_{0}$. If $\theta>0, \sigma_{0}$ becomes the anti-mode.

We see that in the Mallows model, all rankings with the same distance from $\sigma_{0}$ are degenerate in probability. With distance measures that decomposed as a sum like those in equation 3 , we can break the degeneracy by attaching $\theta_{j}$ to each component of the sum (57). For the Kendall and Hamming distance, the Mallows model generalizes using discrepancy measures

Equation 7:

$$
\begin{aligned}
& d_{k}\left(\pi, \pi_{0} ; \boldsymbol{\theta}\right)=\sum_{j=1}^{n-1} \theta_{j} V_{j}\left(\pi \pi_{0}^{-1}\right), \\
& d_{h}\left(\pi, \pi_{0} ; \boldsymbol{\theta}\right)=\sum_{j=1}^{n} \theta_{j} H_{j}\left(\pi \pi_{0}^{-1}\right),
\end{aligned}
$$

such that

Equation 8:

$$
P(\pi)=\frac{e^{d_{k, h}\left(\pi, \sigma_{0} ; \boldsymbol{\theta}\right)}}{\psi(\theta)}
$$

where $\theta=\left(\theta_{1}, \theta_{2}, \cdots\right)$. The central ranking $\sigma_{0}$ and $\theta$ can be estimated by maximum likelihood or other approximate techniques.

The value of $V_{j}(\sigma)$ in equation 3 gives the number of items in $j+1: n$ which are ranked before $j$ in $\sigma$. Therefore, the parameters $\theta_{j}$ reflect the strength of a ranking around the consensus $\sigma_{0}(j)=i$ in that the larger $\theta_{j}$ the larger the probability that $\pi(j) \leq i$. That is, large $\theta_{j}$ in the generalized Mallows model with the Kendall distance implies that item $j$ is ranking in the first $i$ positions with high probability across all the rankings. Similarly, $H_{j}(\sigma)$ of the Hamming distance counts the rank discrepancies. Thus, the parameter $\theta_{j}$ corresponds to the strength of consensus at rank $j$; large $\theta_{j}$ implies high agreement on the item at the $j$-th rank.

\section{A2: Hamming parameters}

To better see the strength of consensus in the rankings across items, the Hamming $\theta_{j}$ parameters against the cross-entropy of a criterion's rank is shown in Figure A1. The cross-entropy measures the amount of impurity in the ranks,

$$
e_{j}=-\sum_{i=1}^{15} p_{i j} \log \left(p_{i j}\right)
$$

where $j$ is the item label, $i$ denotes the rank, and $p_{i j}$ gives the probability of the $i$-th rank for item $j$. Criteria with large rank dispersion have high cross-entropy. The Hamming $\theta_{j}$ parameters also measure the strength of consensus at a given rank.

Figure A1 shows criteria separating into three basic clusters with increasing consensus appearing towards the southeast corner of the plot. Under the Hamming model, the respondents have particularity strong agreement on the criteria at rank 1, 2 and 15.

\section{Figure A1: Kendall and Hamming distances of each respondent's ranking from the generalized Mallows model rankings}

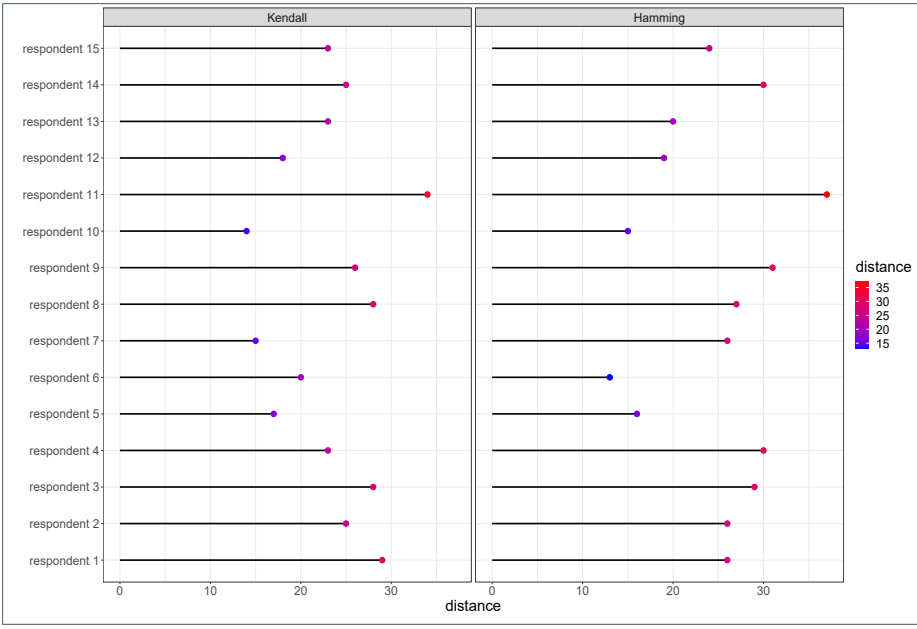

\section{A3: Formal conditions of Arrow's Impossibility Theorem}

Suppose that we are asked to extract a preference order on a given set of options for society. Each individual provides a preference order on the set of outcomes. We desire a ranked voting electoral system, the preference aggregation rule or social welfare function, which transforms the set of preferences into a single global societal preference order. Arrow's theorem says that if there are at least two members in the society and at least three options to decide among, then it is impossible to design a preference aggregation rule that satisfies all of the conditions below at once (conditions assumed to define a "fair system"):

- Non-dictatorship: The social welfare function should account for the wishes of all voters 
- Unrestricted domain, or universality: Each set of individual voter preferences should produce a unique and complete ranking of societal choices from the social welfare function. Thus:

- It must result in a complete ranking of preferences for society

- It must be deterministic; each time the preferences are presented in the same way, the welfare function generates the same societal preference order
- Independence of irrelevant alternatives (IIA): The social preference between two choices should depend only on the individual preferences between changes in rankings of irrelevant alternatives should have no impact on the societal ranking

- Monotonicity, or positive association of social and individual values: If any individual changes a preference order by promoting a choice, then the societal preference order should either promote that same choice in the new ranking or leave it at the same position. An individual should not be able to penalize a choice by increasing its preference

- Non-imposition, or citizen sovereignty: Every possible societal preference order should be achievable by some set of individual preferences 